Article:

\title{
Enhanced Oxidation of Phenol by Copper- catalyzed Fenton-like Reaction in the Presence of Bicarbonate
}

\author{
Hak-Hyeon Kim ${ }^{1}$, Hongshin Lee ${ }^{1}$, Noh-Back Park², Byeong-Dae Lee ${ }^{*}, 3$, Changha Lee*,1 \\ ${ }^{1}$ School of Urban and Environmental Engineering, Ulsan National Institute of Science and Technology (UNIST), 50 \\ UNIST-gil, Ulju-gun, Ulsan 44919, Republic of Korea \\ 2Jeju Fisheries Research Institute, National Fisheries Research and Development Institute (NFRDI), 6 \\ Yeondaemaeul-gil, Jeju-si, Jeju-do, 63068, Republic of Korea \\ ${ }^{3}$ Geologic Environment Division, Korea Institute of Geoscience and Mineral Resources (KIGAM), Gwahang-no 124, \\ Yuseong-gu, Daejeon 34132, Republic of Korea \\ *,3blee@kigam.re.kr.,",clee@unist.ac.kr
}

\begin{abstract}
In this study, the copper-catalyzed Fenton-like reaction in the presence of bicarbonate (i.e., the $\mathrm{Cu}(\mathrm{II}) / \mathrm{HCO}_{3} / \mathrm{H}_{2} \mathrm{O}_{2}$ system) was examined for the phenol degradation. The rate of phenol degradation by the copper-catalyzed Fenton-like reaction $\left([\mathrm{Cu}(\mathrm{II})]_{0}=\right.$ $0.1 \mathrm{mM},\left[\mathrm{H}_{2} \mathrm{O}_{2}\right]_{0}=10 \mathrm{mM}, \mathrm{pH}=10$ ) was accelerated by 17 -fold in the presence of $50 \mathrm{mM} \mathrm{HCO}_{3}^{-}$. The rate of phenol degradation by the $\mathrm{Cu}(\mathrm{II}) / \mathrm{HCO}_{3}^{-} / \mathrm{H}_{2} \mathrm{O}_{2}$ system increased with increasing doses of $\mathrm{Cu}(\mathrm{II})$ and $\mathrm{HCO}_{3}^{-}$, but showed an optimal value for the $\mathrm{H}_{2} \mathrm{O}_{2}$ dose and $\mathrm{pH}$ at $5 \mathrm{mM}$ and 10 , respectively. The $\mathrm{Cu}(\mathrm{II}) / \mathrm{HCO}_{3} / \mathrm{H}_{2} \mathrm{O}_{2}$ system was selective in degrading phenolic compounds; benzoic acid was resistant to degradation. $\mathrm{Cu}$ (III) species (likely complexed forms with carbonate) are believed to be the reactive oxidants responsible for the phenol degradation by the $\mathrm{Cu}(\mathrm{II}) / \mathrm{HCO}_{3}-\mathrm{H}_{2} \mathrm{O}_{2}$ system. Meanwhile, aerating $\mathrm{CO}_{2}$ gas successfully accelerated the phenol degradation by the copper-catalyzed Fenton-like reaction, implying that $\mathrm{CO}_{2}$ aeration can be a practical option to supply bicarbonate when implementing the $\mathrm{Cu}(\mathrm{II}) / \mathrm{HCO}_{3}-\mathrm{H}_{2} \mathrm{O}_{2}$ system.
\end{abstract}

Keywords

Copper; Fenton-like Reaction; Phenol; Hydrogen Peroxide; Bicarbonate

Received: April 11, 2017; Revised: June 11, 2017; Accepted: August 17, 2017

\section{Introduction}

For decades, the use of pharmaceuticals and personal care products (PPCPs) has increased tremendously with increasing concerns about hygiene and health care with population growth [1]. Phenol and its derivatives have been widely used as essential precursors in the manufacturing of PPCPs [2]. However, many PPCPs and phenolic compounds are not effectively degraded by conventional water treatment, including biodegradation. Trace amounts (a few ng/L) of these compounds are frequently detected in surface water [3, 4], causing concerns about potential contamination of drinking water.

Advanced oxidation technologies (AOTs) based on the Fenton and Fenton-like reactions have been extensively studied as effective tools to degrade recalcitrant organic compounds in wastewater [5]. Recently, copper-catalyzed Fenton-like reactions (i.e., the $\mathrm{Cu}(\mathrm{II}) / \mathrm{H}_{2} \mathrm{O}_{2}$ system and its modifications) have been shown to degrade organic 
compounds under neutral and basic $\mathrm{pH}$ conditions [6-8]. These systems also have been suggested as effective methods to inactivate microorganisms $[9,10]$ and control membrane biofouling [11]. The cupryl (Cu(III)) species were proposed as the reactive oxidants dominantly produced by the copper-catalyzed Fenton-like reactions [8].

Meanwhile, several recent studies have reported that copper-catalyzed Fenton-like reactions can be enhanced in by the presence of bicarbonate $\left(\mathrm{HCO}_{3}{ }^{-}\right)$, demonstrating successful degradation of organic compounds, such as dyes [12] and an antimicrobial agent [13]. The enhanced reactions in the presence of $\mathrm{HCO}_{3}{ }^{-}$are believed to result because $\mathrm{Cu}$ (II)-carbonate complexes are more reactive in the catalytic decomposition of $\mathrm{H}_{2} \mathrm{O}_{2}$ into reactive oxidants than the $\mathrm{Cu}$ (II) species without $\mathrm{H}_{2} \mathrm{O}_{2}$ (e.g., $\mathrm{Cu}$ (II)-hydroxo complexes or $\mathrm{Cu}$ (II) oxide). $\mathrm{Cu}$ (III) species [12] and hydroxyl radical $\left({ }^{\circ} \mathrm{OH}\right)$ [13] were suggested as major oxidants responsible for the degradation of organic compounds. However, despite these references $[12,13]$, little information is available for the $\mathrm{Cu}(\mathrm{II}) / \mathrm{HCO}_{3}-/ \mathrm{H}_{2} \mathrm{O}_{2}$ system. Phenolic compounds have not been examined as target contaminants in the $\mathrm{Cu}(\mathrm{II}) / \mathrm{HCO}_{3}-/ \mathrm{H}_{2} \mathrm{O}_{2}$ system. In addition, information about factors such as $\mathrm{pH}$ and doses of reagents $\left(\mathrm{Cu}(\mathrm{II}), \mathrm{HCO}_{3}^{-}\right.$, and $\left.\mathrm{H}_{2} \mathrm{O}_{2}\right)$, as well as the efficiency of $\mathrm{H}_{2} \mathrm{O}_{2}$ use, have not been clearly reported. Moreover, further discussion is needed on the major oxidant produced by the $\mathrm{Cu}(\mathrm{II}) / \mathrm{HCO}_{3}-/ \mathrm{H}_{2} \mathrm{O}_{2}$ system; the reactive oxidants suggested by the two previous studies contradict each other $[12,13]$.

The objectives of this study are (i) to assess the potential of the $\mathrm{Cu}(\mathrm{II}) / \mathrm{HCO}_{3}-/ \mathrm{H}_{2} \mathrm{O}_{2}$ system for degrading phenol by investigating factors that affect the phenol degradation rate, and (ii) to discuss the reactive oxidants mainly responsible for the phenol degradation by the $\mathrm{Cu}(\mathrm{II}) / \mathrm{HCO}_{3}-/ \mathrm{H}_{2} \mathrm{O}_{2}$ system. For these purposes, we examined phenol degradation by the $\mathrm{Cu}(\mathrm{II}) / \mathrm{HCO}_{3} / \mathrm{H}_{2} \mathrm{O}_{2}$ system with various levels of $\mathrm{pH}$ and doses of reagents. The $\mathrm{Cu}(\mathrm{II}) / \mathrm{H}_{2} \mathrm{O}_{2} / \mathrm{HCO}_{3}{ }^{-}$system was compared to the $\mathrm{Co}(\mathrm{II}) / \mathrm{HCO}_{3}{ }^{-} / \mathrm{H}_{2} \mathrm{O}_{2}$ system, a similar Fenton-like system enhanced by $\mathrm{HCO}_{3}{ }^{-}$[14-16]. The degradation of several other organic compounds, such as benzoic acid, bisphenol A, and 4chlorophenol, was also examined. To gain insight into the reactive oxidants produced by the system, experiments using scavengers and a probe compound of reactive oxidants were performed. In addition, aerating $\mathrm{CO}_{2}$ gas was tested as a means of supplying $\mathrm{HCO}_{3}{ }^{-}$to the $\mathrm{Cu}(\mathrm{II}) / \mathrm{H}_{2} \mathrm{O}_{2}$ system.

\section{Materials and methods}

\section{Reagents}

All chemicals were of reagent grade and used without further purification. Acetonitrile and 2,9-dimethyl-1,10phenanthroline (DMP, Neocuproine) were from J.T. Baker ${ }^{\circledR}$ (USA) and TCI Co. (Japan), respectively, and all the other chemicals were obtained from Sigma-Aldrich Co. (USA). $18.2 \mathrm{M} \Omega \cdot \mathrm{cm}$ Milli-Q water from a Millipore system was used to prepare solutions. $\mathrm{CuSO}_{4}$ was used to prepare the $\mathrm{Cu}(\mathrm{II})$ stock solution $(10 \mathrm{mM})$. The stock solution of sodium bicarbonate $\left(\mathrm{NaHCO}_{3}\right)(0.5 \mathrm{M})$ was prepared freshly prior to the experiment.

\section{Experimental Setup and Procedure}

All experiments were conducted in a $125 \mathrm{~mL}$ Erlenmeyer flask open to the atmosphere at room temperature (22 \pm $2^{\circ} \mathrm{C}$ ). For some experiments, the solution was aerated with ultrapure $\mathrm{CO}_{2}$ gas using a diffuser for saturation (for 30 min prior to the experiment). The solution $\mathrm{pH}$ was adjusted using a $1 \mathrm{~N} \mathrm{HClO}_{4}$ and $1 \mathrm{~N} \mathrm{NaOH}$ solution. The solutions for $\mathrm{pH} 7$ and 8 were buffered with 5 and $1 \mathrm{mM}$ phosphate, respectively. In all experiments, $\mathrm{pH}$ variations were less than 0.3 units during the reaction. The reaction was initiated by adding hydrogen peroxide $\left(\mathrm{H}_{2} \mathrm{O}_{2}\right)$ to the prepared solution containing $\mathrm{Cu}(\mathrm{II})$ and the organic compound (and $\mathrm{HCO}_{3}{ }^{-}$). Samples were withdrawn using a 10 $\mathrm{mL}$ glass syringe at predetermined times and filtered through a $0.2-\mu \mathrm{m}$ hydrophilic PTFE filter. The possible reactions of $\mathrm{Cu}(\mathrm{II})$ in samples were immediately quenched by adding $20 \mu \mathrm{L}$ of $200 \mathrm{mM}$ ethylenediaminetetraacetic acid (EDTA). All experiments were carried out at least in triplicate, and the average values and standard deviations (error bars) were presented. Main experimental conditions include: $[\mathrm{Cu}(\mathrm{II})]_{0}=0.1 \mathrm{mM},\left[\mathrm{HCO}_{3}^{-}\right]_{0}=50 \mathrm{mM},\left[\mathrm{H}_{2} \mathrm{O}_{2}\right]_{0}=$ $10 \mathrm{mM}$, $[\mathrm{Phenol}]_{0}=0.1 \mathrm{mM}$, and $\mathrm{pH}=10$. For some experiments, the doses of $\mathrm{Cu}(\mathrm{II}), \mathrm{HCO}_{3}{ }^{-}, \mathrm{H}_{2} \mathrm{O}_{2}$, and $\mathrm{pH}$ were varied in the ranges of $0.001-0.1 \mathrm{mM}, 1-100 \mathrm{mM}, 1-100 \mathrm{mM}$, and 7-12, respectively. All the experimental conditions were summarized in Table S1 in the supplementary data. 


\section{Analytical Methods}

The concentration of organic compounds was measured by high-performance liquid chromatography (HPLC; Dionex Ultimate 3000; Thermo Fisher Scientific Inc., USA) with UV absorbance detection (at 277, 230, 230, $227 \mathrm{~nm}$ for phenol, 4-chlorophenol, bisphenol A, and benzoic acid, respectively). Separation was performed on an Agilent Eclipse XDB - C18 column $(150 \mathrm{~mm} \times 4.6 \mathrm{~mm}, 5 \mu \mathrm{m})$ using a binary mixture of $0.1 \%(\mathrm{w} / \mathrm{w})$ phosphoric acid solution and acetonitrile as an eluent at a flow rate of $1.5 \mathrm{~mL} / \mathrm{min} . \mathrm{H}_{2} \mathrm{O}_{2}$ was analyzed using the titanium sulfate method on a UV/Vis spectrophotometer (S-3100; Scinco Co., Korea) [17]. Reactive Black 5 (RB5) was analyzed by measuring the absorbance at $597 \mathrm{~nm}$. Chemical oxygen demand (COD) was analyzed by the $\mathrm{KMnO}_{4}$ method using a COD analysis kit (COD-Mn-L; Humas Co., Korea).

\section{Results}

\section{Phenol Degradation by the $\mathrm{Cu}(\mathrm{II}) / \mathrm{HCO}_{3} / \mathrm{H}_{2} \mathrm{O}_{2}$ System: Comparison to the $\mathrm{Co}(\mathrm{II}) / \mathrm{HCO}_{3} / \mathrm{H}_{2} \mathrm{O}_{2} \mathrm{System}$}

The $\mathrm{Cu}(\mathrm{II}) / \mathrm{HCO}_{3}-\mathrm{H}_{2} \mathrm{O}_{2}$ system degraded phenol (approximately $90 \%$ degradation in $2 \mathrm{~h}$ ) much better than the $\mathrm{Cu}(\mathrm{II}) / \mathrm{H}_{2} \mathrm{O}_{2}$ system $\left(10 \%\right.$ degradation in $2 \mathrm{~h}$ ) (Figure $1 \mathrm{a}$ ); the phenol degradation by $\mathrm{Cu}(\mathrm{II}) / \mathrm{HCO}_{3}{ }^{-}$and $\mathrm{H}_{2} \mathrm{O}_{2} / \mathrm{HCO}_{3}{ }^{-}$ was negligible. The COD removal was $38 \%$ in $2 \mathrm{~h}$ during the phenol degradation (Figure $\mathrm{S} 1$ in the supplementary data) The decomposition of $\mathrm{H}_{2} \mathrm{O}_{2}$ was also greater in the $\mathrm{Cu}(\mathrm{II}) / \mathrm{HCO}_{3}-\mathrm{H}_{2} \mathrm{O}_{2}$ system than in the $\mathrm{Cu}(\mathrm{II}) / \mathrm{H}_{2} \mathrm{O}_{2}$ system (Figure $1 \mathrm{~b}$ ), indicating that $\mathrm{HCO}_{3}^{-}$accelerates the $\mathrm{Cu}(\mathrm{II})$-catalyzed decomposition of $\mathrm{H}_{2} \mathrm{O}_{2}$ to increase the production of reactive oxidants that can degrade phenol.
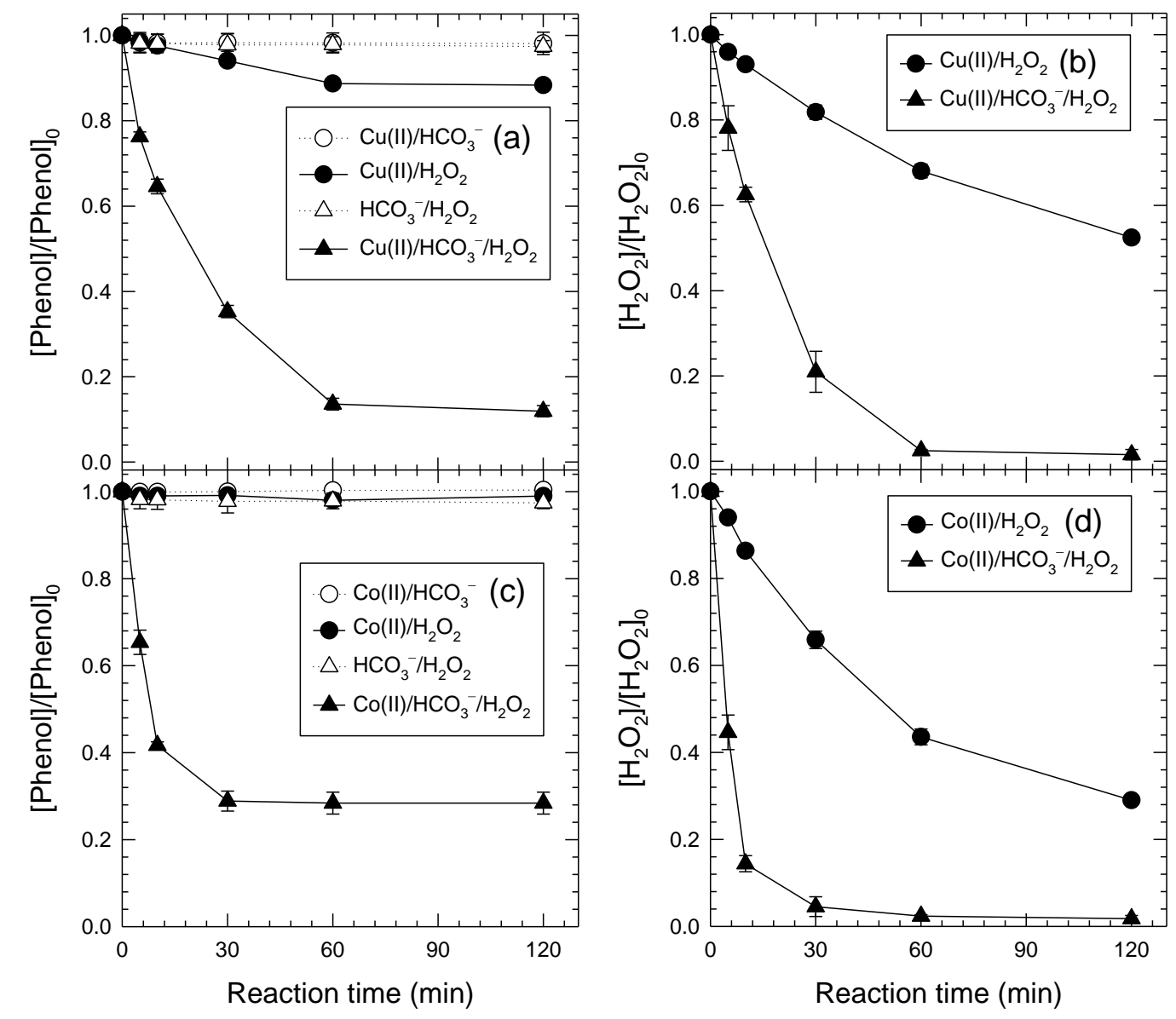

FIG. 1 DEGRADATION OF PHENOL AND DECOMPOSITION OF $\mathrm{H}_{2} \mathrm{O}_{2}$ BY THE Cu(II)/ $/ \mathrm{HCO}_{3}-/ \mathrm{H}_{2} \mathrm{O}_{2} \mathrm{SYSTEM}_{(\mathrm{a}}$, b) AND BY THE $\mathrm{Co}(\mathrm{II}) / \mathrm{HCO}_{3}{ }^{-} / \mathrm{H}_{2} \mathrm{O}_{2}$ SYSTEM (c, d) $\left([\mathrm{PHENOL}]_{0}=0.1 \mathrm{mM} ;[\mathrm{Cu}(\mathrm{II})]_{0}=[\mathrm{Co}(\mathrm{II})]_{0}=0.1 \mathrm{mM} ;\left[\mathrm{HCO}_{3}{ }^{-}\right]_{0}=50 \mathrm{mM} ;\left[\mathrm{H}_{2} \mathrm{O}_{2}\right]_{0}=10 \mathrm{mM} ; \mathrm{pH}=10.0\right)$ 
The $\mathrm{Co}(\mathrm{II}) / \mathrm{HCO}_{3}{ }^{-} / \mathrm{H}_{2} \mathrm{O}_{2}$ system (a similar $\mathrm{HCO}_{3}{ }^{-}$-enhanced Fenton-like system) led to $72 \%$ degradation of phenol under the same conditions (Figure 1c); phenol was not degraded by other combinations, such as $\mathrm{Co}(\mathrm{II}) / \mathrm{HCO}_{3}^{-}$, $\mathrm{Co}(\mathrm{II}) / \mathrm{H}_{2} \mathrm{O}_{2}$, and $\mathrm{H}_{2} \mathrm{O}_{2} / \mathrm{HCO}_{3}{ }^{-}$. Like the $\mathrm{Cu}(\mathrm{II})$-catalyzed systems, the $\mathrm{Co}(\mathrm{II}) / \mathrm{HCO}_{3}{ }^{-} / \mathrm{H}_{2} \mathrm{O}_{2}$ system exhibited greater $\mathrm{H}_{2} \mathrm{O}_{2}$ decomposition than the $\mathrm{Co}(\mathrm{II}) / \mathrm{H}_{2} \mathrm{O}_{2}$ system (Figure $1 \mathrm{~d}$ ).

Comparing the $\mathrm{Cu}(\mathrm{II}) / \mathrm{HCO}_{3}-/ \mathrm{H}_{2} \mathrm{O}_{2}$ and $\mathrm{Co}(\mathrm{II}) / \mathrm{HCO}_{3}-/ \mathrm{H}_{2} \mathrm{O}_{2}$ systems (Figures $1 \mathrm{a}$ and $1 \mathrm{~b}$ versus Figures $1 \mathrm{c}$ and $1 \mathrm{~d}$ ), the rates of phenol degradation and $\mathrm{H}_{2} \mathrm{O}_{2}$ decomposition were higher in the $\mathrm{Co}(\mathrm{II}) / \mathrm{HCO}_{3}-/ \mathrm{H}_{2} \mathrm{O}_{2}$ system than in the $\mathrm{Cu}(\mathrm{II}) / \mathrm{HCO}_{3}-/ \mathrm{H}_{2} \mathrm{O}_{2}$ system. However, the degree of phenol degradation was greater in the $\mathrm{Cu}(\mathrm{II}) / \mathrm{HCO}_{3}-\mathrm{H}_{2} \mathrm{O}_{2}$ system $(90 \%$ degradation in $60 \mathrm{~min})$ than in the $\mathrm{Co}(\mathrm{II}) / \mathrm{HCO}_{3}-/ \mathrm{H}_{2} \mathrm{O}_{2}$ system $(72 \%$ degradation in $30 \mathrm{~min})$. As a result, the $\mathrm{H}_{2} \mathrm{O}_{2}$ use efficiencies (i.e., $\Delta[\mathrm{Phenol}] / \Delta\left[\mathrm{H}_{2} \mathrm{O}_{2}\right]$, calculated from the results of Figure 1 ) were higher in the $\mathrm{Cu}(\mathrm{II}) / \mathrm{HCO}_{3}-\mathrm{H}_{2} \mathrm{O}_{2}$ system than in the $\mathrm{Co}(\mathrm{II}) / \mathrm{HCO}_{3}-\mathrm{H}_{2} \mathrm{O}_{2}$ system (Figure $\mathrm{S} 2$ in the supplementary data).

\section{Effects of $\mathrm{Cu}(\mathrm{II}), \mathrm{HCO}_{3}{ }^{-}, \mathrm{H}_{2} \mathrm{O}_{2}$ Doses, and Solution $\mathrm{pH}$}

The effects of $\mathrm{Cu}(\mathrm{II}), \mathrm{HCO}_{3}^{-}$, and $\mathrm{H}_{2} \mathrm{O}_{2}$ doses on the degradation of phenol were examined in the $\mathrm{Cu}(\mathrm{II}) / \mathrm{HCO}_{3}-\mathrm{H}_{2} \mathrm{O}_{2}$ system (Figure 2). The rate of phenol degradation was presented by the pseudo-first order rate constant $(k)$, which was determined using the data points that satisfy $\mathrm{R}^{2}>0.9$ (those for $50-70 \%$ phenol degradation depending on the condition). The $k$ value increased with increasing doses of $\mathrm{Cu}(\mathrm{II})$ and $\mathrm{HCO}_{3}{ }^{-}$. However, when the $\mathrm{H}_{2} \mathrm{O}_{2}$ dose was adjusted, the optimal rate of phenol degradation was observed at $5 \mathrm{mM} \mathrm{H}_{2} \mathrm{O}_{2}$.

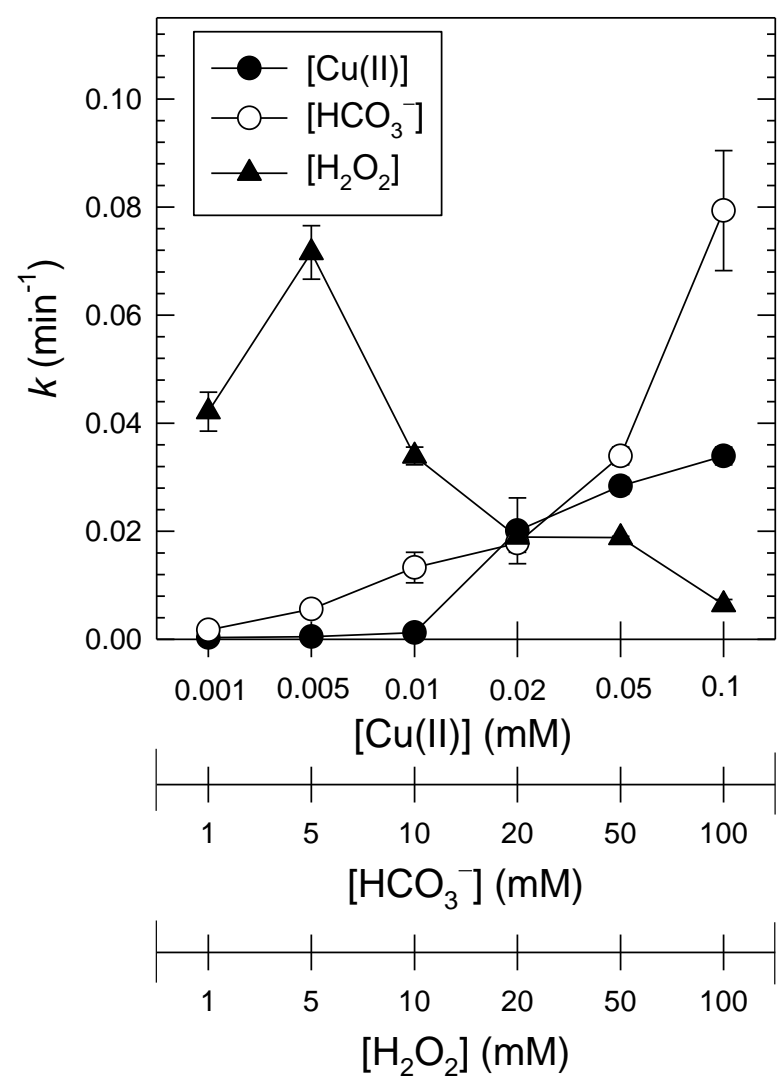

FIG. 2 EFFECTS OF $\mathrm{Cu}(\mathrm{II}), \mathrm{HCO}_{3}{ }^{-}$, AND $\mathrm{H}_{2} \mathrm{O}_{2}$ DOSES ON THE PHENOL DEGRADATION RATE BY THE Cu(II)/ $/ \mathrm{HCO}_{3}-/ \mathrm{H}_{2} \mathrm{O}_{2} \mathrm{SYSTEM}$ $\left([\mathrm{PHENOL}]_{0}=0.1 \mathrm{mM} ; \mathrm{pH}=10.0 ;[\mathrm{Cu}(\mathrm{II})]_{0}=0.1 \mathrm{mM}\right.$ FOR VARIOUS DOSES OF $\mathrm{HCO}_{3}-\mathrm{AND} \mathrm{H}_{2} \mathrm{O}_{2} ;\left[\mathrm{HCO}_{3}{ }^{-}\right]_{0}=50$ mM FOR VARIOUS DOSES $\mathrm{OF} \mathrm{Cu}(\mathrm{II})$ AND $\mathrm{H}_{2} \mathrm{O}_{2} ;\left[\mathrm{H}_{2} \mathrm{O}_{2}\right]_{0}=10 \mathrm{mM}$ FOR VARIOUS DOSES OF $\mathrm{Cu}(\mathrm{II}) \mathrm{AND} \mathrm{HCO}_{3}^{-}$).

The phenol degradation by the $\mathrm{Cu}(\mathrm{II}) / \mathrm{HCO}_{3}-\mathrm{H}_{2} \mathrm{O}_{2}$ system was optimal at $\mathrm{pH} 10$ (Figure 3a); the $k$ value increased with increasing $\mathrm{pH}$ from 7 to 10, then drastically decreased under alkaline $\mathrm{pH}$ conditions. However, the rate of $\mathrm{H}_{2} \mathrm{O}_{2}$ decomposition continued to increase with increasing $\mathrm{pH}$ from 7 to 12 (Figure 3b). In addition, RB5 (believed to be more vulnerable to oxidation [6,7]) was employed as a reference target compound to investigate the $\mathrm{pH}$ effect. Contrary to phenol, RB5 was degraded faster under alkaline $\mathrm{pH}$ conditions (Figure 3c), exhibiting a similar trend to the $\mathrm{H}_{2} \mathrm{O}_{2}$ decomposition (Figure 3b). 


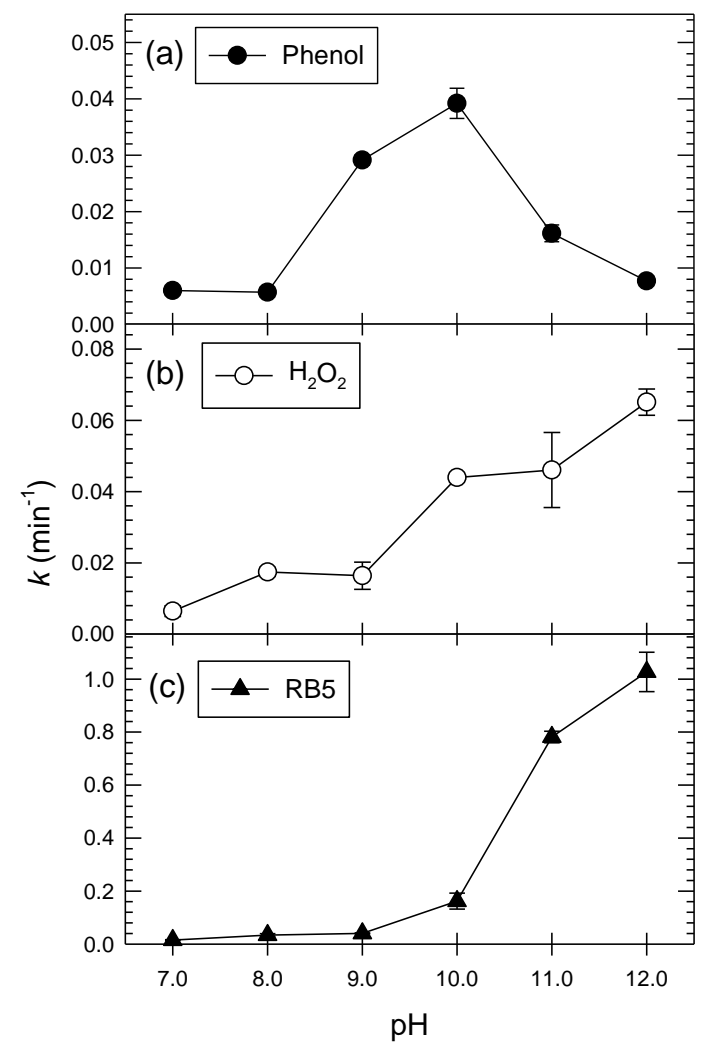

FIG. 3 RATES OF PHENOL DEGRADATION (a), $\mathrm{H}_{2} \mathrm{O}_{2}$ DECOMPOSITION (b), AND RB5 DEGRADATION (c) AS A FUNCTION OF pH $\left([\mathrm{PHENOL}]_{0}=0.1 \mathrm{mM} ;\left[\mathrm{H}_{2} \mathrm{O}_{2}\right]_{0}=10 \mathrm{mM} ;[\mathrm{RB} 5]_{0}=50 \mathrm{mG} / \mathrm{L} ;[\mathrm{Cu}(\mathrm{II})]_{0}=0.1 \mathrm{mM} ;\left[\mathrm{HCO}_{3}^{-}\right]_{0}=50 \mathrm{mM}\right)$

\section{Degradation of Selected Organic Compounds}

Several organic compounds (benzoic acid, bisphenol A, and 4-chlorophenol) were also tested for degradation by the $\mathrm{Cu}(\mathrm{II}) / \mathrm{HCO}_{3}-/ \mathrm{H}_{2} \mathrm{O}_{2}$ system (Figure 4). Benzoic acid was resistant to degradation, whereas the other compounds were successfully degraded, exhibiting degradation kinetics similar to that of phenol.

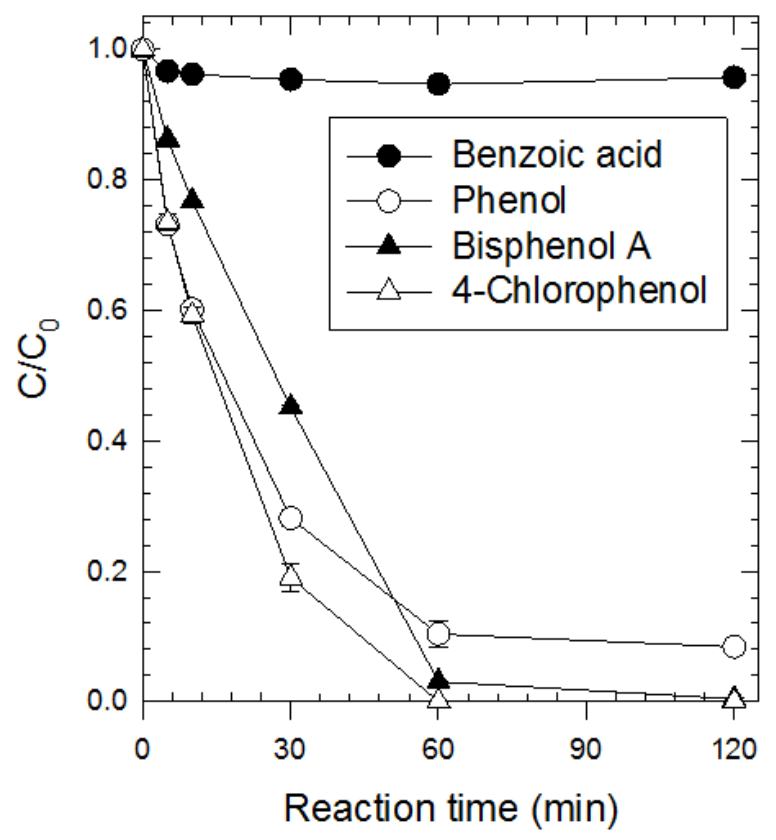

FIG. 4 DEGRADATION OF SEVERAL ORGANIC COMPOUNDS BY THE $\mathrm{Cu}(\mathrm{II}) / \mathrm{HCO}_{3}-/ \mathrm{H}_{2} \mathrm{O}_{2} \mathrm{SYSTEM}\left([\mathrm{BENZOIC} \mathrm{ACID}]_{0}=[\mathrm{PHENOL}]_{0}=\right.$ $\left.[\text { BISPHENOL A }]_{0}=[4-\mathrm{CHLOROPHENOL}]_{0}=0.1 \mathrm{mM} ;[\mathrm{Cu}(\mathrm{II})]_{0}=0.1 \mathrm{MM} ;\left[\mathrm{HCO}_{3}{ }^{-}\right]_{0}=50 \mathrm{mM} ;\left[\mathrm{H}_{2} \mathrm{O}_{2}\right]_{0}=10 \mathrm{mM} ; \mathrm{pH}=10.0\right)$ 


\section{Effects of Oxidant Scavengers and Copper-chelating Agents}

Effects of oxidant scavengers (methanol and tert-butanol) on the rate of phenol degradation were examined in the $\mathrm{Cu}(\mathrm{II}) / \mathrm{HCO}_{3}-\mathrm{H}_{2} \mathrm{O}_{2}$ system (Figure 5). The addition of methanol inhibited phenol degradation; the $k$ value gradually decreased from $0.034 \mathrm{~min}^{-1}$ to $0.020 \mathrm{~min}^{-1}$ when the input concentration of methanol increased up to $1 \mathrm{M}$. On the other hand, tert-butanol did not inhibit the phenol degradation; in fact, the $k$ value increased with the increasing concentration of tert-butanol.

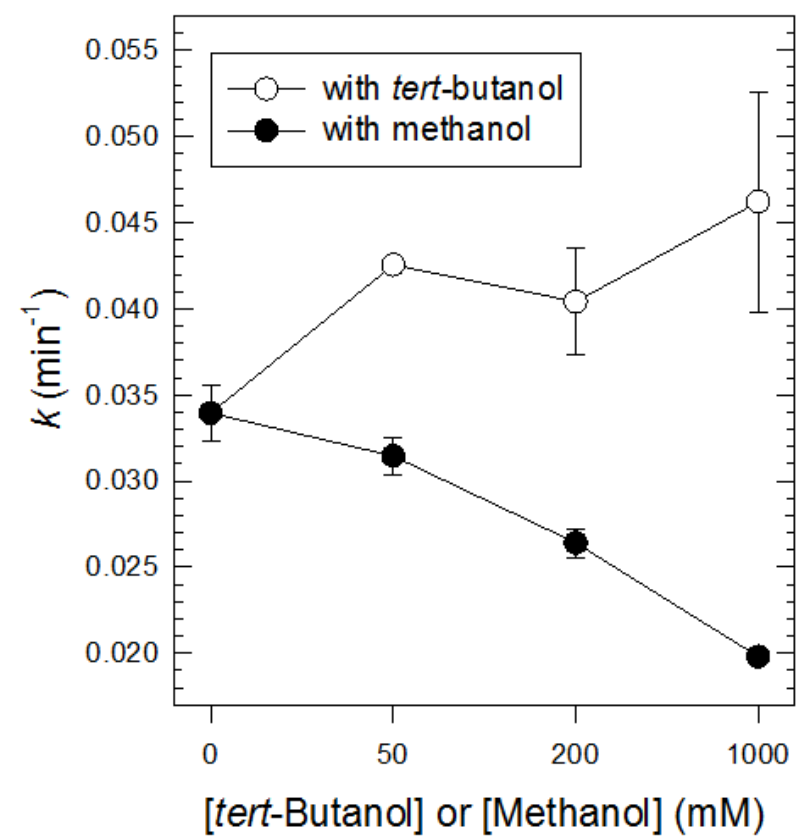

FIG. 5 EFFECTS OF OXIDANT SCAVENGERS (tert-BUTANOL AND METHANOL) ON THE PHENOL DEGRADATION RATE BY THE $\mathrm{Cu}(\mathrm{II}) / \mathrm{HCO}_{3}-/ \mathrm{H}_{2} \mathrm{O}_{2}$ SYSTEM $\left([\mathrm{PHENOL}]_{0}=0.1 \mathrm{mM} ;[\mathrm{Cu}(\mathrm{II})]_{0}=0.1 \mathrm{mM} ;\left[\mathrm{HCO}_{3}{ }^{-}\right]_{0}=50 \mathrm{mM} ;\left[\mathrm{H}_{2} \mathrm{O}_{2}\right]_{0}=10 \mathrm{mM} ; \mathrm{pH}=10.0\right)$

The addition of copper-chelating agents such as EDTA, DMP, and citrate significantly inhibited the phenol degradation by the $\mathrm{Cu}(\mathrm{II}) / \mathrm{HCO}_{3}-\mathrm{H}_{2} \mathrm{O}_{2}$ system (Figure 6). EDTA completely stopped the phenol degradation, and DMP and citrate led to less than $10 \%$ of phenol degradation in $2 \mathrm{~h}$.

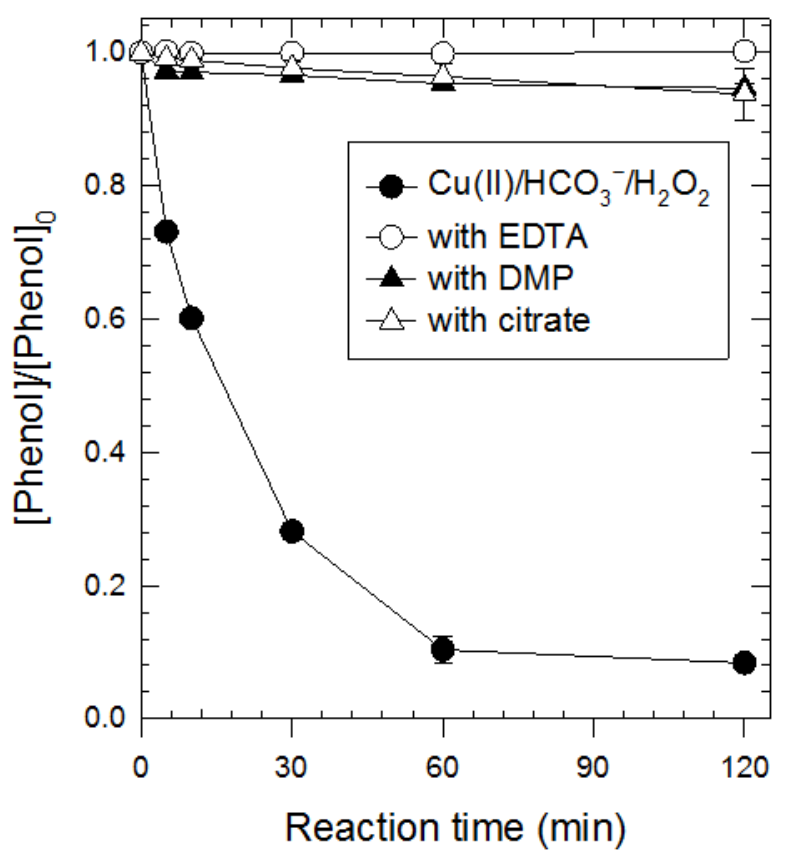

FIG. 6 EFFECTS OF COPPER-CHELATING AGENTS ON PHENOL DEGRADATION BY THE Cu(II)/ $/ \mathrm{HCO}_{3}{ }^{-} / \mathrm{H}_{2} \mathrm{O}_{2}$ SYSTEM $\left([\mathrm{PHENOL}]_{0}=0.1\right.$ $\left.\mathrm{mM} ;[\mathrm{Cu}(\mathrm{II})]_{0}=0.1 \mathrm{mM} ;[\mathrm{EDTA}]_{0}=[\mathrm{DMP}]_{0}=[\mathrm{CITRATE}]_{0}=10 \mathrm{mM} ;\left[\mathrm{H}_{2} \mathrm{O}_{2}\right]_{0}=10 \mathrm{mM} ;\left[\mathrm{HCO}_{3}^{-}\right]_{0}=50 \mathrm{mM} ; \mathrm{pH}=10.0\right)$ 


\section{Aeration of $\mathrm{CO}_{2}$ in the $\mathrm{Cu}(\mathrm{II}) / \mathrm{H}_{2} \mathrm{O}_{2}$ System}

To explore the potential of $\mathrm{CO}_{2}$ for supplying $\mathrm{HCO}_{3}{ }^{-}$, the phenol degradation by the $\mathrm{Cu}(\mathrm{II}) / \mathrm{H}_{2} \mathrm{O}_{2}$ system was examined by aerating $\mathrm{CO}_{2}$ into the solution. As shown in Figure 7 , the $\mathrm{Cu}(\mathrm{II}) / \mathrm{H}_{2} \mathrm{O}_{2}$ system with $\mathrm{CO}_{2}$ aeration degraded phenol better than that without $\mathrm{CO}_{2}$ aeration, indicating that $\mathrm{CO}_{2}$ aeration is indeed effective in supplying $\mathrm{HCO}_{3}{ }^{-}$to the $\mathrm{Cu}(\mathrm{II}) / \mathrm{H}_{2} \mathrm{O}_{2}$ system. The measured alkalinity of the $\mathrm{CO}_{2}$-aerated solution was equivalent to that of the $43.3 \mathrm{mM} \mathrm{HCO}^{-}$solution.

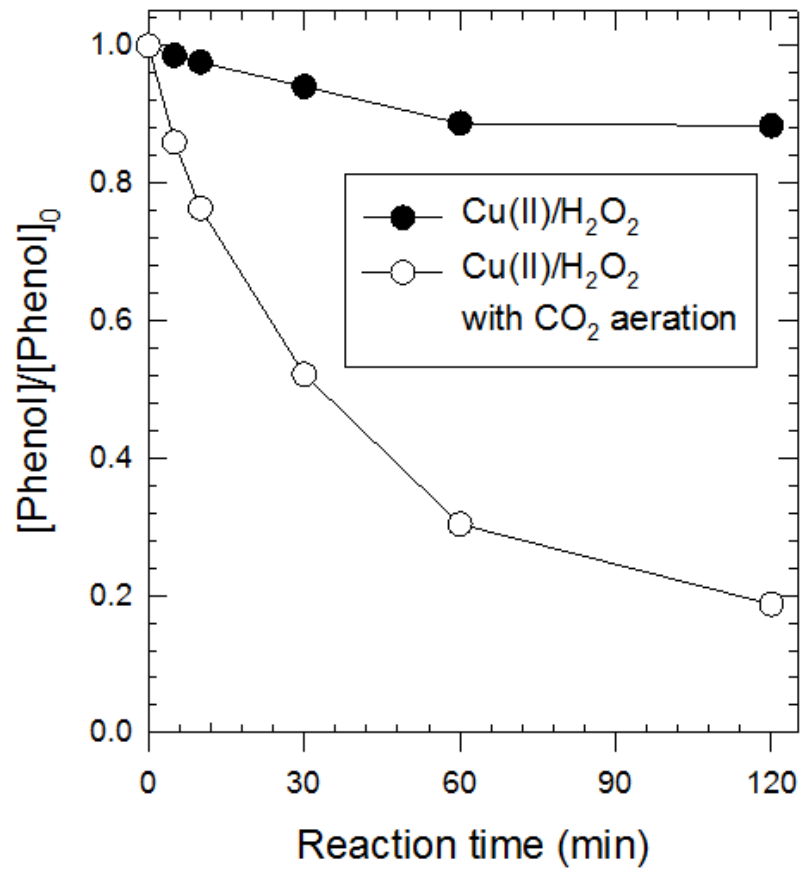

FIG. 7 DEGRADATION OF PHENOL BY THE Cu(II)/ $\mathrm{H}_{2} \mathrm{O}_{2}$ SYSTEM WITH CO $\mathrm{CO}_{2}$ AERATION $\left([\mathrm{PHENOL}]_{0}=0.1 \mathrm{mM} ;[\mathrm{Cu}(\mathrm{II})]_{0}=0.1 \mathrm{mM} ;\left[\mathrm{H}_{2} \mathrm{O}_{2}\right]_{0}=\right.$ $10 \mathrm{mM} ; \mathrm{pH}=10.0)$

\section{Discussion}

\section{Production of Reactive Oxidants by the $\mathrm{Cu}(\mathrm{II}) / \mathrm{HCO}_{3}-/ \mathrm{H}_{2} \mathrm{O}_{2}$ System}

The $\mathrm{Cu}(\mathrm{II}) / \mathrm{H}_{2} \mathrm{O}_{2}$ system is known to produce reactive oxidants via the Fenton-like reaction mechanism $[7,18,19]$. $\mathrm{Cu}(\mathrm{II})$ is reduced to $\mathrm{Cu}(\mathrm{I})$ by the reaction with $\mathrm{H}_{2} \mathrm{O}_{2}$, producing superoxide radical anion $\left(\mathrm{O}_{2}{ }^{\circ}\right)$ (reaction 1$)$. Then, the reaction of $\mathrm{Cu}(\mathrm{I})$ with $\mathrm{H}_{2} \mathrm{O}_{2}$ produces reactive oxidants, i.e., ${ }^{\bullet} \mathrm{OH}$ and $\mathrm{Cu}(\mathrm{III})$ (reaction 2); ${ }^{\bullet} \mathrm{OH}$ and $\mathrm{Cu}$ (III) are produced by the one-electron and two-electron transfer reactions, respectively. Reaction 1 is believed to be slower than reaction 2, becoming the rate-determining step (RDS) for the production of reactive oxidants [7].

$$
\begin{gathered}
\mathrm{Cu}(\mathrm{II})+\mathrm{H}_{2} \mathrm{O}_{2} \rightarrow \mathrm{Cu}(\mathrm{I})+\mathrm{O}_{2}{ }^{-}+2 \mathrm{H}^{+} \\
\mathrm{Cu}(\mathrm{I})+\mathrm{H}_{2} \mathrm{O}_{2} \rightarrow \mathrm{Cu}(\mathrm{II})+{ }^{\bullet} \mathrm{OH}+\mathrm{OH}^{-} \text {or } \mathrm{Cu}(\mathrm{III})+2 \mathrm{OH}^{-}
\end{gathered}
$$

The addition of $\mathrm{HCO}_{3}{ }^{-}$can change the kinetics of the reaction of $\mathrm{Cu}(\mathrm{II})$ with $\mathrm{H}_{2} \mathrm{O}_{2}$ by forming $\mathrm{Cu}$ (II)-carbonate complexes. In the presence of $\mathrm{HCO}_{3}^{-}(50 \mathrm{mM}), \mathrm{Cu}(\mathrm{II})$-carbonate complexes form in the $\mathrm{pH}$ range of 4-11 (Figure S3 in the supplementary data). These complexes are believed to have higher reactivity with $\mathrm{H}_{2} \mathrm{O}_{2}$ than those in the absence of $\mathrm{HCO}_{3}^{-}$(e.g., $\mathrm{Cu}$ (II)-hydroxo complexes and $\mathrm{Cu}(\mathrm{II})$ oxide); the decomposition of $\mathrm{H}_{2} \mathrm{O}_{2}$ was indeed accelerated in the presence of $\mathrm{HCO}_{3}{ }^{-}$(Figure $1 \mathrm{~b}$ ). When strong $\mathrm{Cu}(\mathrm{II})$-chelating agents, such as citrate, EDTA, and DMP, were added to the $\mathrm{Cu}(\mathrm{II}) / \mathrm{HCO}_{3}^{-} / \mathrm{H}_{2} \mathrm{O}_{2}$ system (to replace $\mathrm{Cu}$ (II)-carbonate complexes with the $\mathrm{Cu}$ (II) complexes of added ligands), the phenol degradation was almost completely blocked (Figure 6 in the supplementary data), confirming the critical roles of $\mathrm{Cu}(\mathrm{II})$-carbonate complexes.

On the other hand, it has been reported that $\mathrm{HCO}_{3}{ }^{-}$can directly react with $\mathrm{H}_{2} \mathrm{O}_{2}$ to produce peroxymonocarbonate $\left(\mathrm{HCO}_{4}^{-}\right)$(Reaction 3) $[20,21] . \mathrm{HCO}_{4}^{-}$as a strong oxidant $\left(E^{\circ}\left[\mathrm{HCO}_{4}^{-} / \mathrm{HCO}_{3}^{-}\right]=1.8 \mathrm{VNHE}[20]\right)$ is known to oxidize 
sulfides [20], dyes, and 4-chlorophenol [21].

$$
\mathrm{HCO}_{3}{ }^{-}+\mathrm{H}_{2} \mathrm{O}_{2} \rightarrow \mathrm{HCO}_{4}^{-}+\mathrm{H}_{2} \mathrm{O}
$$

However, phenol degradation by the $\mathrm{H}_{2} \mathrm{O}_{2} / \mathrm{HCO}_{3}^{-}$system was negligible under the conditions employed in this study (Figure 1). It appears that much higher concentrations of $\mathrm{HCO}_{3}{ }^{-}$and $\mathrm{H}_{2} \mathrm{O}_{2}$ may be required to generate a significant level of $\mathrm{HCO}_{4}^{-}$.

Compared to the $\mathrm{Co}(\mathrm{II}) / \mathrm{HCO}_{3}-/ \mathrm{H}_{2} \mathrm{O}_{2}$ system (a similar Fenton-like system), the $\mathrm{Cu}(\mathrm{II}) / \mathrm{HCO}_{3}-\mathrm{H}_{2} \mathrm{O}_{2}$ system appears to have lower catalytic activity for decomposing $\mathrm{H}_{2} \mathrm{O}_{2}$ into reactive oxidants; the rates of both phenol degradation and $\mathrm{H}_{2} \mathrm{O}_{2}$ decomposition were lower (Figure 1). However, the $\mathrm{Cu}(\mathrm{II}) / \mathrm{HCO}_{3}-/ \mathrm{H}_{2} \mathrm{O}_{2}$ system used $\mathrm{H}_{2} \mathrm{O}_{2}$ more efficiently (Figure S2 in the supplementary data), implying that the yields of reactive oxidants are higher or that reactive oxidants that are more selective toward the reaction with phenol are generated.

\section{Nature of Reactive Oxidants}

Earlier studies suggested that $\mathrm{Cu}(\mathrm{III})$ species are the major reactive oxidants produced by the $\mathrm{Cu}(\mathrm{II}) / \mathrm{H}_{2} \mathrm{O}_{2}$ system under neutral and alkaline $\mathrm{pH}$ conditions $[6,7,19]$, and that ${ }^{\circ} \mathrm{OH}$ may be dominantly produced under lower $\mathrm{pH}$ conditions [6, 7]. However, more recently, Lee et al. suggested that $\mathrm{Cu}(\mathrm{III})$ species are dominantly produced regardless of $\mathrm{pH}$ in the $\mathrm{Cu}(\mathrm{II}) / \mathrm{H}_{2} \mathrm{O}_{2}$ system, and that they exhibit ${ }^{\circ} \mathrm{OH}-$ like reactivity [8].

In the $\mathrm{Cu}(\mathrm{II}) / \mathrm{HCO}_{3}-/ \mathrm{H}_{2} \mathrm{O}_{2}$ system, discrepant views were presented about the identity of the reactive oxidants [12, 13]. Cheng et al. [12] and Peng et al. [13] suggested $\mathrm{Cu}(\mathrm{III})$ and ${ }^{\circ} \mathrm{OH}$ as the major reactive oxidants, respectively. This discrepancy appears to result mainly from different observations of the effects of radical scavengers, which did not inhibit the degradation of the target compound in Cheng et al.'s study, whereas Peng et al. observed significant inhibitory effects by radical scavengers. However, the inhibitory effects by typical ${ }^{\circ} \mathrm{OH}$ scavengers, such as 2-propanol and tert-butanol, do not necessarily identify ${ }^{\circ} \mathrm{OH}$ as the major reactive oxidant, because the ${ }^{\circ} \mathrm{OH}$ scavengers can also react with $\mathrm{Cu}(\mathrm{III})[8,19]$. Various $\mathrm{Cu}(\mathrm{III})$ species of different reactivity can exist, depending on their ligands, and some of them can have high reactivity with 2-propanol and tert-butanol.

Experimental results in this study present evidence against ${ }^{\circ} \mathrm{OH}$, supporting the production of $\mathrm{Cu}(\mathrm{III})$ species as major reactive oxidants in the $\mathrm{Cu}(\mathrm{II}) / \mathrm{HCO}_{3}-/ \mathrm{H}_{2} \mathrm{O}_{2}$ system. First, the failure of excess tert-butanol to quench the phenol degradation is not explained by the reaction of ${ }^{\bullet} \mathrm{OH}$ (Figure 5); the rate of phenol degradation instead increased, for which no clear explanation can be provided. Although the addition of methanol somewhat inhibited the phenol degradation (Figure 5), the degree of inhibition ( $40 \%$ decrease of $k$ at $1 \mathrm{M}$ methanol) is far from the observation anticipated from the reaction of ${ }^{\circ} \mathrm{OH}$. The concentrations and second-order rate constants of the compounds present in the solution were as follows:

$$
\begin{aligned}
& {[\text { Phenol }]_{0}=0.1 \mathrm{mM}, k\left({ }^{\circ} \mathrm{OH}+\text { phenol }(\text { at } \mathrm{pH} 10)\right)=8.3 \times 10^{9} \mathrm{M}^{-1} \mathrm{~s}^{-1} ;} \\
& {\left[\mathrm{H}_{2} \mathrm{O}_{2}\right]_{0}=10 \mathrm{mM}, k\left({ }^{\bullet} \mathrm{OH}+\mathrm{H}_{2} \mathrm{O}_{2}\right)=3 \times 10^{7} \mathrm{M}^{-1} \mathrm{~s}^{-1} ;} \\
& {\left[\mathrm{HCO}_{3}{ }^{-}\right]_{0}=50 \mathrm{mM}, k\left({ }^{\circ} \mathrm{OH}+\mathrm{HCO}_{3}-\mathrm{CO}_{3}{ }^{2-}(\text { at } \mathrm{pH} 10)\right)=1.4 \times 10^{8} \mathrm{M}^{-1} \mathrm{~s}^{-1} ;} \\
& {[\text { Methanol }]=1 \mathrm{M}, k(\cdot \mathrm{OH}+\text { methanol })=9.7 \times 10^{8} \mathrm{M}^{-1} \mathrm{~s}^{-1}[22],}
\end{aligned}
$$

Given these concentrations, almost complete quenching of ${ }^{\circ} \mathrm{OH}$ by $1 \mathrm{M}$ methanol would be anticipated. Second, the negligible degradation of benzoic acid (Figure 4) also weighs against the reaction of ${ }^{\circ} \mathrm{OH}$; in fact, the second-order rate constant of benzoic acid (benzoate, $k\left({ }^{\circ} \mathrm{OH}+\right.$ benzoate $\left.)=5.9 \times 10^{9} \mathrm{M}^{-1} \mathrm{~s}^{-1}\right)$ is comparable to that of phenol $\left(k\left({ }^{\circ} \mathrm{OH}\right.\right.$ + phenol $($ at $\left.\mathrm{pH} 10))=8.3 \times 10^{9} \mathrm{M}^{-1} \mathrm{~s}^{-1}\right)$ [22]

The reactivity of $\mathrm{Cu}(\mathrm{III})$ species (likely present as $\mathrm{Cu}(\mathrm{III})$ complexes) is believed to vary with the ligands coordinated to $\mathrm{Cu}(\mathrm{III})$. Different $\mathrm{Cu}(\mathrm{III})$ species including $\mathrm{Cu}(\mathrm{III})$-carbonate complexes can be produced by the $\mathrm{Cu}(\mathrm{II}) / \mathrm{HCO}_{3}-/ \mathrm{H}_{2} \mathrm{O}_{2}$ system, and the speciation of these $\mathrm{Cu}(\mathrm{III})$ complexes is determined by several parameters, such as $\mathrm{pH}$ and concentrations of $\mathrm{Cu}(\mathrm{III})$ and $\mathrm{HCO}_{3}{ }^{-}$. Therefore, the reactivity of $\mathrm{Cu}(\mathrm{III})$ species formed in the $\mathrm{Cu}(\mathrm{II}) / \mathrm{HCO}_{3}-/ \mathrm{H}_{2} \mathrm{O}_{2}$ system can vary depending on these parameters. 
The different trends in the $\mathrm{pH}$-dependency of phenol and RB5 degradation by the $\mathrm{Cu}(\mathrm{II}) / \mathrm{HCO}_{3}-\mathrm{H}_{2} \mathrm{O}_{2}$ system (Figures 3a and 3c) may be attributed to the $\mathrm{pH}$-dependent $\mathrm{Cu}(\mathrm{III})$ speciation. At $\mathrm{pH}>10$, weaker oxidizing species (which can degrade RB5 but hardly phenol) appear to be formed; these species may be $\mathrm{Cu}$ (III)-hydroxo complexes with high coordination numbers, e.g., $\mathrm{Cu}(\mathrm{OH})_{3}, \mathrm{Cu}(\mathrm{OH})_{4}^{-}$, etc.

The discrepant effects of oxidant scavengers observed by previous studies [12, 13] are also likely due to the occurrence of $\mathrm{Cu}(\mathrm{III})$ species of different reactivities. Cheng et al. [12] used higher concentrations of $\mathrm{Cu}(\mathrm{II})$ and $\mathrm{HCO}_{3}{ }^{-}$than Peng et al. [13]; this difference may have affected the speciation of $\mathrm{Cu}(\mathrm{III})$, producing $\mathrm{Cu}(\mathrm{III})$ species of different reactivities with the oxidant scavengers.

\section{Factors Affecting the Production of Reactive Oxidants}

In the $\mathrm{Cu}(\mathrm{II}) / \mathrm{HCO}_{3}{ }^{-} / \mathrm{H}_{2} \mathrm{O}_{2}$ system, factors such as $\mathrm{pH}$ and doses of $\mathrm{Cu}(\mathrm{II}), \mathrm{HCO}_{3}{ }^{-}$and $\mathrm{H}_{2} \mathrm{O}_{2}$ affect the production of reactive oxidants and the resultant phenol degradation. Increasing doses of $\mathrm{Cu}(\mathrm{II})$ and $\mathrm{HCO}_{3}{ }^{-}$increased the rate of phenol degradation (Figure 2). The increase in the dose of $\mathrm{Cu}(\mathrm{II})$ (as a catalyst) accelerates the catalytic decomposition of $\mathrm{H}_{2} \mathrm{O}_{2}$ into reactive oxidants. In addition, the increase in the dose of $\mathrm{HCO}_{3}^{-}$leads to increased formation of $\mathrm{Cu}$ (II)-carbonate complexes that are believed to have higher reactivity with $\mathrm{H}_{2} \mathrm{O}_{2}$ than those in the absence of $\mathrm{HCO}_{3}^{-}$(e.g., $\mathrm{Cu}$ (II) oxide). According to the calculation using MINEQL+ 4.6, more $\mathrm{Cu}$ (II)-carbonate complexes, such as $\mathrm{CuCO}_{3}$ and $\mathrm{Cu}\left(\mathrm{CO}_{3}\right)_{2^{2-}}$, evolved under mild alkaline conditions when the dose of $\mathrm{HCO}_{3}$ increased from $1 \mathrm{mM}$ to $100 \mathrm{mM}$ (Figure $\mathrm{S} 4$ in the supplementary data).

For the $\mathrm{H}_{2} \mathrm{O}_{2}$ dose, the rate of phenol degradation was maximized at $5 \mathrm{mM} \mathrm{H}_{2} \mathrm{O}_{2}$ (Figure 2). The inhibitory effect at $\left[\mathrm{H}_{2} \mathrm{O}_{2}\right]>5 \mathrm{mM}$ is attributed to the scavenging of reactive oxidants by excess $\mathrm{H}_{2} \mathrm{O}_{2}$. Considering that the phenol degradation was not inhibited (or slowed down) by an excess amount of $\mathrm{HCO}_{3}{ }^{-}$, the reactions of reactive oxidants (likely $\mathrm{Cu}(\mathrm{III})$-carbonate complexes) may be more selective to $\mathrm{H}_{2} \mathrm{O}_{2}$ than $\mathrm{HCO}_{3}{ }^{-}$. Note that, for ${ }^{\circ} \mathrm{OH}$, the reaction with $\mathrm{HCO}_{3}{ }^{-}$is even faster than that with $\mathrm{H}_{2} \mathrm{O}_{2}$ (refer to $k\left({ }^{\circ} \mathrm{OH}+\mathrm{H}_{2} \mathrm{O}_{2}\right)=3 \times 10^{7} \mathrm{M}^{-1} \mathrm{~s}^{-1}$ and $k\left({ }^{\circ} \mathrm{OH}+\mathrm{HCO}_{3} / \mathrm{CO}_{3}{ }^{2-}(\right.$ at $\left.\mathrm{pH} 10))=1.4 \times 10^{8} \mathrm{M}^{-1} \mathrm{~s}^{-1}[22]\right)$.

The phenol degradation was optimized at $\mathrm{pH} 10$ (Figure 3a). The degradation of phenol at $\mathrm{pH}<10$ accelerates because the catalytic decomposition of $\mathrm{H}_{2} \mathrm{O}_{2}$ into reactive oxidants accelerates with increasing $\mathrm{pH}$ (Figure $3 \mathrm{~b}$ ). The reduction of $\mathrm{Cu}(\mathrm{II})$ by $\mathrm{H}_{2} \mathrm{O}_{2}$ (reaction 1 , RDS) accelerates with increasing $\mathrm{pH}$ because the reaction proceeds via the complexation of $\mathrm{Cu}$ (II) with a deprotonated form of $\mathrm{H}_{2} \mathrm{O}_{2}\left(\mathrm{HO}_{2}{ }^{-}, \mathrm{pK}\right.$ a of $\left.\mathrm{H}_{2} \mathrm{O}_{2}=11.75\right)$ as the primary step. As described in Section 4.2, at $\mathrm{pH}>10$, weaker $\mathrm{Cu}(\mathrm{III})$ species that hardly degrade phenol may arise.

\section{Applications of the $\mathrm{Cu}(\mathrm{II}) / \mathrm{HCO}_{3}-\mathrm{H}_{2} \mathrm{O}_{2}$ System}

The $\mathrm{Cu}(\mathrm{II}) / \mathrm{HCO}_{3}-\mathrm{H}_{2} \mathrm{O}_{2}$ system can potentially be used to oxidize refractory organic contaminants in water and wastewater. For practical application, $\mathrm{Cu}(\mathrm{II})$ needs to be immobilized in order to recycle the catalyst and minimize the (eco)toxic impacts of released copper ions. Particularly for treating drinking water, the concentration of released copper ions should be controlled at less than $1 \mathrm{mg} / \mathrm{L}$; the regulation levels of copper in Korea and the United States are $1 \mathrm{mg} / \mathrm{L}(15.7 \mu \mathrm{M})$ and $1.3 \mathrm{mg} / \mathrm{L}(20.5 \mu \mathrm{M})$, respectively [23, 24].

In addition, as demonstrated in Figure 7, aeration by $\mathrm{CO}_{2}$ gas is an effective alternative for supplying $\mathrm{HCO}_{3}{ }^{-}$into water to implement the $\mathrm{Cu}(\mathrm{II}) / \mathrm{HCO}_{3}-\mathrm{H}_{2} \mathrm{O}_{2}$ system. When the $\mathrm{Cu}(\mathrm{II}) / \mathrm{HCO}_{3}-\mathrm{H}_{2} \mathrm{O}_{2}$ system is used to treat industrial wastewater, waste $\mathrm{CO}_{2}$ discharged by neighboring industries may be used for this purpose.

\section{Conclusions}

The $\mathrm{Cu}(\mathrm{II}) / \mathrm{HCO}_{3}-/ \mathrm{H}_{2} \mathrm{O}_{2}$ system was shown to effectively degrade phenolic compounds, better than $\mathrm{Cu}(\mathrm{II}) / \mathrm{H}_{2} \mathrm{O}_{2}$ system. $\mathrm{Cu}$ (II)-carbonate complexes formed in the presence of $\mathrm{HCO}_{3}{ }^{-}$appear to have higher catalytic activity for decomposing $\mathrm{H}_{2} \mathrm{O}_{2}$ into reactive oxidants. $\mathrm{Cu}$ (III) species (likely complexed forms with carbonate) may be the major reactive oxidants responsible for the phenol degradation. Several parameters, such as $\mathrm{pH}$ and doses of $\mathrm{Cu}(\mathrm{II})$, $\mathrm{HCO}_{3}^{-}$, and $\mathrm{H}_{2} \mathrm{O}_{2}$, influenced the rate of phenol degradation by affecting the generation and consumption of reactive oxidants as well as their speciation. The $\mathrm{Cu}(\mathrm{II}) / \mathrm{HCO}_{3}-\mathrm{H}_{2} \mathrm{O}_{2}$ system can be used to treat water and 
wastewater after addressing such issues as the immobilization and long-term stability of the catalyst, environmental impacts of released copper ions, and economic feasibility.

\section{ACKNOWLedgements}

This work was supported by "The GAIA Project" (2016000550007) funded by the Korea Ministry of Environment, and by a grant from the National Institute of Fisheries Science (R2017006).

\section{References}

[1] Khetan, S. K.; Collins, T. J. Chem. Rev. 2007, 107, 2319-2364.

[2] Shioiri, T.; Izawa, K.; Konoike, T. Pharmaceutical process chemistry, Wiley-VCH, Weinheim, Germany, 2011.

[3] Heberer, T. Toxicol. Lett. 2002, 131, 5-17.

[4] Kolpin, D. W.; Furlong, E. T.; Meyer, M. T.; Thurman, E. M.; Zaugg, S. D.; Barber, L. B.; Buxton, H. T. Environ. Sci. Technol. 2002, 36, 1202-1211.

[5] Pignatello, J. J.; Oliveros, E.; MacKay, A. Crit. Rev. Env. Sci. Technol. 2006, 36, 1-84.

[6] Lee, H.; Lee, H. -J.; Sedlak, D. L.; Lee, C. Chemosphere 2013, 92, 652-658.

[7] Lee, H. -J.; Lee, H.; Lee, C. Chem. Eng. J, 2014, 245, 258-264.

[8] Lee, H.; Lee, H. -J.; Seo, J.; Kim, H. -E.; Shin, Y. K.; Kim, J. -H.; Lee, C. Environ. Sci. Technol. 2016, 50, 8231-8238.

[9] Nguyen, T. T. M.; Park, H. -J.; Kim, J. Y.; Kim, H. -E.; Lee, H.; Yoon, J.; Lee, C. Environ. Sci. Technol. 2013, 47, 13661-13667.

[10] Kim, H. -E.; Nguyen, T. T. M.; Lee, H.; Lee, C. Environ. Sci. Technol. 2015, 49, 14416-14423.

[11] Lee, H. -J.; Kim, H. -E.; Lee, C. Water Res. 2017, 110, 83-90.

[12] Cheng, L.; Wei, M.; Huang, L.; Pan, F.; Xia, D.; Li, X.; Xu, A. Ind. Eng. Chem. Res. 2014, 53, 3478-3485.

[13] Peng, J.; Shi, H.; Li, J.; Wang, L.; Wang, Z.; Gao, S. Chem. Eng. J. 2016, 306, 484-491.

[14] Xu, A.; Li, X.; Ye, S.; Yin, G.; Zeng, Q. Appl. Catal. B Environ. 2011, 102, 37-43.

[15] Li, X.; Xiong, Z.; Ruan, X.; Xia, D.; Zeng, Q.; Xu, A. Appl. Catal. A General 2012, 411, 24-30.

[16] Zhou, L.; Song, W.; Chen, Z.; Yin, G. Environ. Sci. Technol. 2013, 47, 3833-3839.

[17] Eisenberg, G. Ind. Eng. Chem., Anal. Ed. 1943, 15, 327-328.

[18] Moffett, J. W.; Zika, R. G. Environ. Sci. Technol. 1987, 21, 804-810.

[19] Pham, A. N.; Xing, G.; Miller, C. J.; Waite, T. D. J. Catal. 2013, 301, 54-64.

[20] Richardson, D. E.; Yao, H. R.; Frank, K. M.; Bennett, D. A. J. Am. Chem. Soc. 2000, 122, 1729-1739.

[21] Xu, A.; Li, X.; Xiong, H.; Yin, G. Chemosphere 2011, 82, 1190-1195.

[22] Buxton, G. V.; Greenstock, C. L.; Helman, W. P.; Ross, A. B. J. Phys. Chem. Ref. Data 1988, 17, 513-886.

[23] The Ministry of Environment. Drinking water quality standard and test, Republic of Korea, 2014.

[24] U. S. Environmental Protection Agency. National primary drinking water regulations, United States, 2009. 


\section{Supplementary Data}

TABLE S1. SUMMARY OF EXPERIMENTAL CONDITIONS

\begin{tabular}{|c|c|c|c|c|c|c|c|c|}
\hline No & $\begin{array}{l}\mathrm{Cu}(\mathrm{II}) \\
(\mathrm{mM})\end{array}$ & $\begin{array}{l}\mathrm{Co}(\mathrm{II}) \\
(\mathrm{mM})\end{array}$ & $\mathrm{HCO}_{3}^{-}(\mathrm{mM})$ & $\begin{array}{l}\mathrm{H}_{2} \mathrm{O}_{2} \\
(\mathrm{mM}) \\
\end{array}$ & $\begin{array}{c}\text { Organic compounds } \\
\text { (mM) }\end{array}$ & $\begin{array}{c}\text { Oxidant scavengers } \\
(\mathrm{mM})\end{array}$ & $\mathrm{pH}$ & Figure \\
\hline 1 & 0.1 & - & 50 & 10 & 0.1 (Phenol) & - & 10.0 & $\begin{array}{r}\text { Fig. } 1 \\
(a, b)\end{array}$ \\
\hline 2 & - & 0.1 & 50 & 10 & 0.1 (Phenol) & - & 10.0 & $\begin{array}{l}\text { Fig. } 1 \\
(\mathrm{c}, \mathrm{d}) \\
\end{array}$ \\
\hline 3 & $\begin{array}{c}0.001 \\
0.005 \\
0.01,0.02 \\
0.05,0.1\end{array}$ & - & 50 & 10 & 0.1 (Phenol) & - & 10.0 & Fig. 2 \\
\hline 4 & 0.1 & - & $\begin{array}{c}1,5,10 \\
20,50,100 \\
\end{array}$ & 10 & 0.1 (Phenol) & - & 10.0 & Fig. 2 \\
\hline 5 & 0.1 & - & 10 & $\begin{array}{c}1,5,10 \\
20,50,100 \\
\end{array}$ & 0.1 (Phenol) & - & 10.0 & Fig. 2 \\
\hline 6 & 0.1 & - & 50 & 10 & 0.1 (Phenol) & - & $\begin{array}{c}7.0,8.0,9.0 \\
10.0,11.0 \\
12.0 \\
\end{array}$ & $\begin{array}{l}\text { Fig. } 3 \\
(a, b)\end{array}$ \\
\hline 7 & 0.1 & - & 50 & 10 & $50 \mathrm{mg} / \mathrm{L}$ (RB5) & - & $\begin{array}{c}7.0,8.0,9.0 \\
10.0,11.0 \\
12.0 \\
\end{array}$ & $\begin{array}{l}\text { Fig. } 3 \\
\text { (c) }\end{array}$ \\
\hline 8 & 0.1 & - & 50 & 10 & $\begin{array}{c}0.1 \\
\text { (Benzoic acid, Phenol, } \\
\text { Bisphenol A, } \\
\text { 4-Chlorophenol) }\end{array}$ & - & 10.0 & Fig. 4 \\
\hline 9 & 0.1 & - & 50 & 10 & 0.1 (Phenol) & $\begin{array}{c}50,200,1000 \\
\text { (tert-Butanol, } \\
\text { Methanol) } \\
\end{array}$ & 10.0 & Fig. 5 \\
\hline 10 & 0.1 & - & $\begin{array}{c}\left(\mathrm{CO}_{2}\right. \\
\text { aeration })\end{array}$ & 10 & 0.1 (Phenol) & 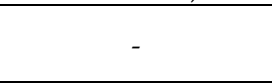 & 10.0 & Fig. 6 \\
\hline
\end{tabular}

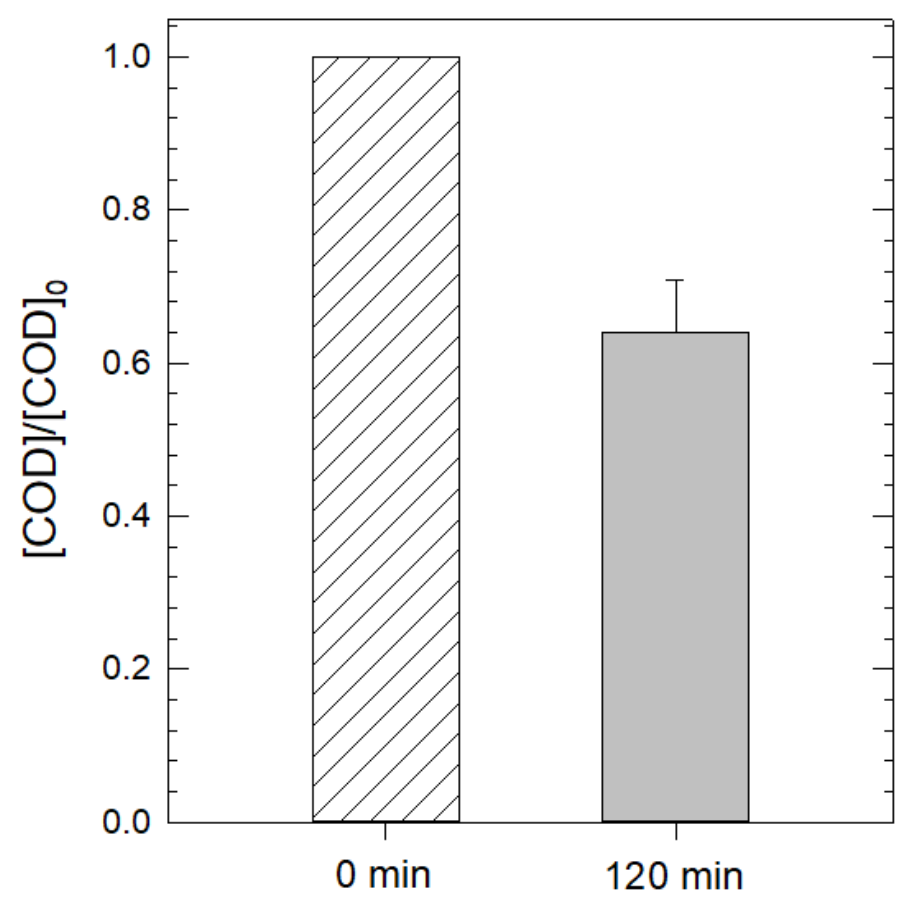

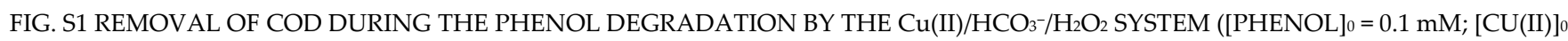
$\left.=0.1 \mathrm{mM} ;\left[\mathrm{HCO}_{3}{ }^{-}\right]_{0}=50 \mathrm{mM} ;\left[\mathrm{H}_{2} \mathrm{O}_{2}\right]_{0}=10 \mathrm{mM} ; \mathrm{pH}=10.0\right)$ 


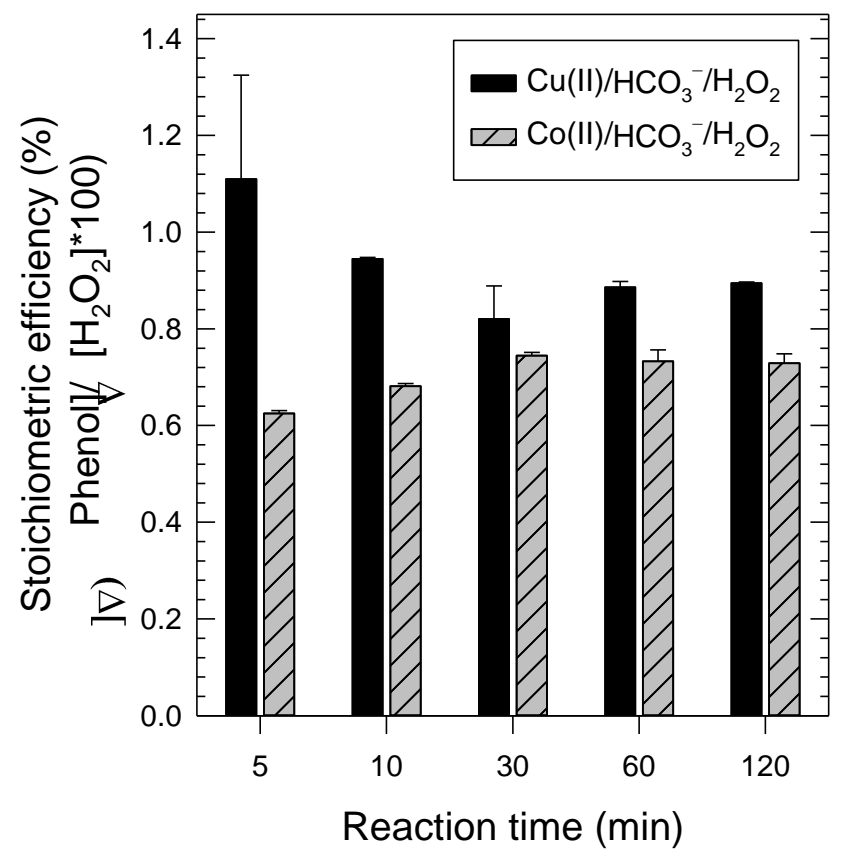

FIG. S2 $\mathrm{H}_{2} \mathrm{O}_{2}$ USE EFFICIENCY FOR PHENOL DEGRADATION BY THE $\mathrm{Cu}(\mathrm{II}) / \mathrm{HCO}_{3}{ }^{-} / \mathrm{H}_{2} \mathrm{O}_{2}$ AND $\mathrm{Co}(\mathrm{II}) / \mathrm{HCO}_{3}-/ \mathrm{H}_{2} \mathrm{O}_{2} \mathrm{SYSTEMS}^{-}$ (CALCULATED FROM THE DATA OF FIGURE 1)
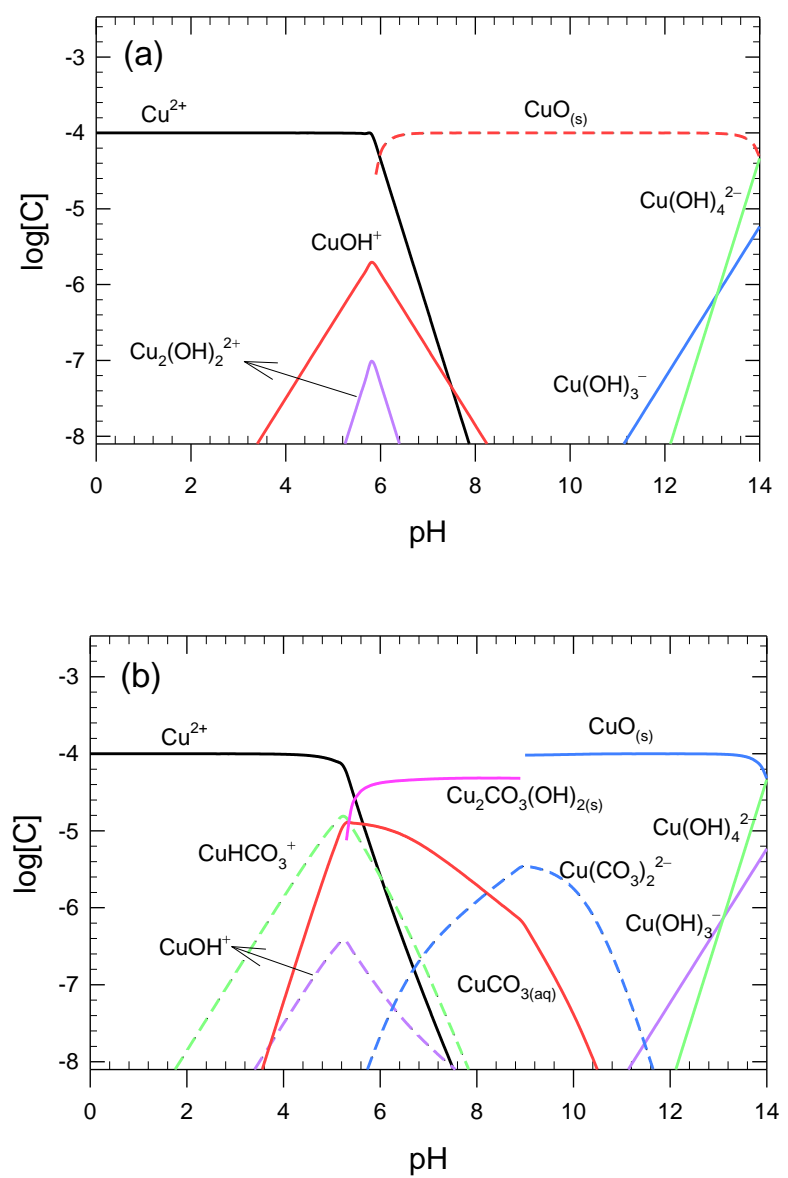

FIG. S3 SPECIATION OF Cu(II) IN THE ABSENCE (a) AND PRESENCE (b) OF HCO ${ }^{-}$, CALCULATED BY MINEQL+ 4.6. ([Cu(II)] = 0.1 mM; $\left.\left[\mathrm{HCO}_{3}{ }^{-}\right]_{0}=50 \mathrm{mM}\right)$ 

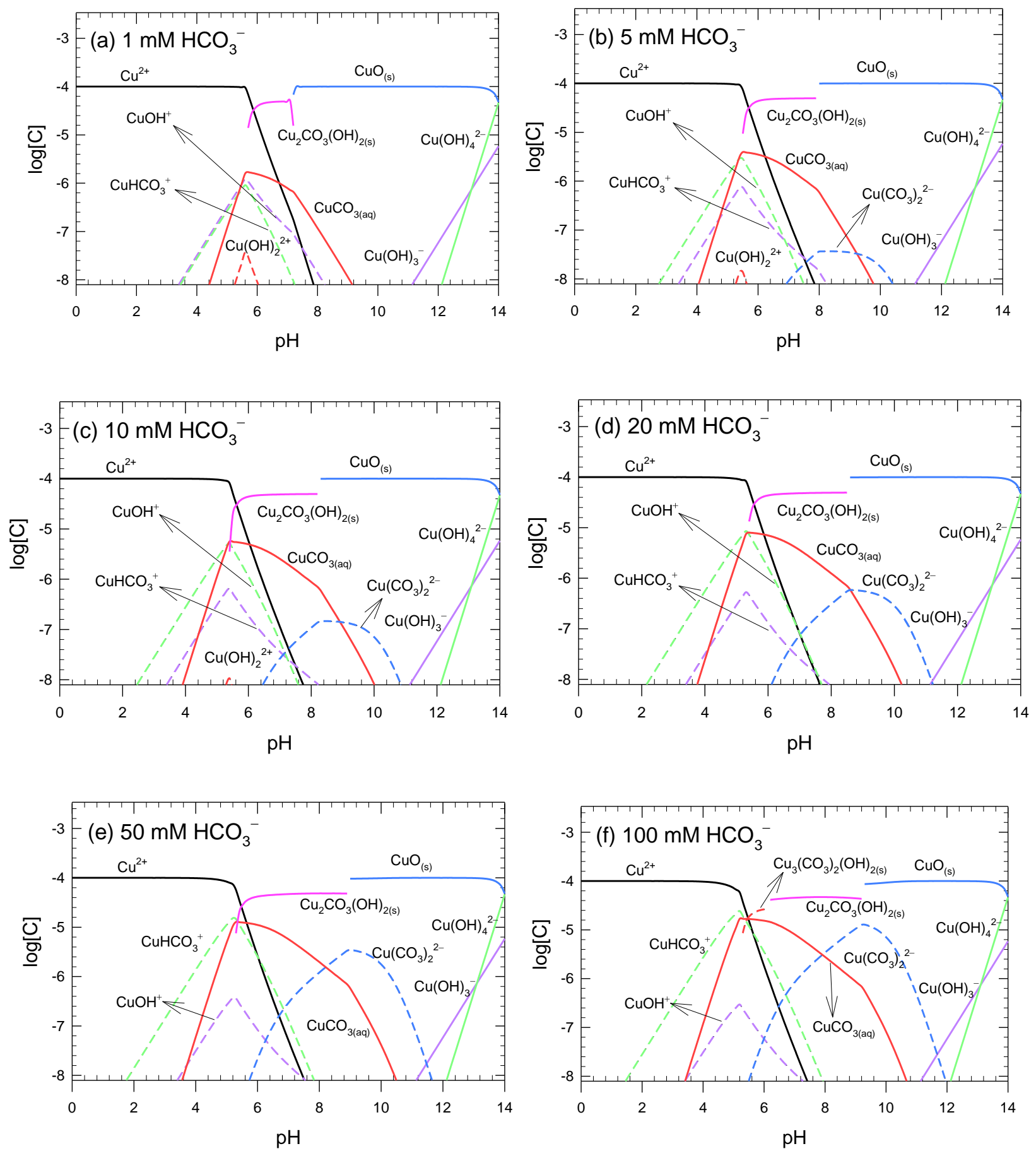

FIG. S4 SPECIATION OF Cu(II) IN THE PRESENCE OF HCO ${ }^{-}$WITH DIFFERENT CONCENTRATIONS, CALCULATED BY MINEQL+ 4.6 $\left([\mathrm{Cu}(\mathrm{II})]_{0}=0.1 \mathrm{mM}\right)$ 